This is the author accepted manuscript of Pemberton, S., 2015. Statecraft, scalecraft and local government reorganisation in Wales. Environment and Planning C: Government and Policy. (C) The Author, Sage Publications, available at: http://dx.doi.org/10.1177/0263774x15610581.

\title{
Statecraft, scalecraft and local government reorganisation in Wales
}

Abstract: Since the inception of local government in the UK, there have been continuous attempts to reorganise and revise its distinctive characteristics, with successive reforms differing in their intended effects. In Wales, a further round of local government reorganisation is now being proposed following the Williams Commission Report (2014) on Public Service Governance and Delivery. Through drawing on the concepts of statecraft and scalecraft, this paper provides a theoretically informative account of the contradictions of the 'layering' process associated with the re-scaling of local government in Wales. This helps to (i) enhance our understanding of contemporary proposals for reform; and (ii) develop a tighter specifying of the process of state rescaling.

Key words: Statecraft, Scalecraft, local government, reorganisation, Wales

\section{Introduction}

In Wales, local government reorganisation is back on the political agenda. In April 2013 the Williams Commission - Chaired by Sir Paul Williams and supported by six other members - was established to examine the ways in which public services are governed and delivered in Wales, and how they may be improved, Whilst the remit of the Commission encapsulated all public services, particular focus was placed on the role of local government (Commission on Public Service, Governance and Delivery, 2014). Just 18 years after the last major structural reorganisation of local government 
in Wales in 1996, the Commission concluded that there should be a reduction in the number of local authorities to deliver more efficient and effective services.

However, we should not be surprised at the latest proposals for territorial restructuring. Since the inception of local government in the United Kingdom (UK) in the nineteenth century, there have been continuous attempts to reorganise and revise its distinctive characteristics - for example, structural, functional, financial and managerial - and with successive reforms differing in their intended effects (Alexander, 1982). Indeed, in Wales, major structural reorganisation to the system set up under the Local Government Act of 1888 was first mooted in 1961, and culminated in a comprehensive restructuring of the local government system in 1974, followed by a further round of reforms being implemented in 1996.

In this context, Brenner (2004, p.76) has drawn attention to the ways in which "historically specific configurations of state space are produced and incessantly reworked”. In other words, new geographies of the state, or 'new state spaces', are constantly being produced as part and parcel of the shifting nature of state institutions and political strategies (Brenner, 2004, p.76). Consequently, there is an on-going concern of all would-be reformers of local government - within Wales, the UK and beyond - in whether to make modest proposals that are easily acceptable to all, or alternatively, to make proposals which are more radical, but which are less likely to be adopted (Pratchett and Wilson, 1996).

However, there has been less focus to date on how this may be achieved, as well as the implications arising for the rescaling of the state. In this respect, Brenner (2009a, 
p.135) has called for a greater focus on delineating the "processes behind the rescaling of the state, as well as the consequences of them”. This point segues into the main contribution of the paper - the development of new insights into the ways in which the structure and scales of local government have evolved through the concepts of 'statecraft' (see Bulpitt, 1983; 1986a; 1986b) and 'scalecraft' (see Fraser, 2010). Indeed, a focus on the interconnections between statecraft and scalecraft facilitates the development of a tighter specifying of the process of state rescaling.

The next section of the paper sets out the background to local government reorganisation in Wales and elaborates how the concepts of statecraft and scalecraft can help inform our understanding of the ways in which reorganisation has unfolded over time and the complexity associated with developing both structural and scalar practices that seek to shape new structures and scales of governance. Section 3 of the paper then applies the concepts of statecraft and scalecraft to excavate and illustrate the contradictions of the 'layering' process associated with the re-scaling of local government in Wales that took place in 1974 and 1996 respectively. This is undertaken through a detailed discursive analysis of the White Papers produced to implement local government reform in Wales in 1974 and 1996. In relation to 1974, analysis is supplemented through drawing upon Hansard proceedings of debates in the House of Commons on local government reorganisation in Wales. These provide a revealing insight into the ways in which issues of statecraft and scalecraft were of relevance in terms of informing the ways in which government implemented reorganisation, as well as opposition to the reforms. 
For the later structural reorganisation that took place in 1996, discursive analysis of the Local Government White Paper (which formalized the proposals for reform) is considered alongside more readily available academic and policy literature, as well as Hansard proceedings. This information is also augmented through interview material with individuals who were involved in reorganisation during this period.

The conclusion (Section 4) subsequently highlights broader concerns with the contested production of scale and 'scalar politics' (see, for example, Mackinnon, 2011; Cox, 2009; Allen and Cochrane, 2010). It additionally draws out the insights that arise from a comparison of the entwining of statecraft and scalecraft associated with each of the previous reforms for contemporary proposals for local government restructuring in Wales (due to commence in 2018), as well as studies of local government change in other institutional, political and socio-economic contexts.

\section{Local government reorganisation, statecraft and scalecraft}

Brenner (2009a, p.135) has recently called for a greater focus on the 'periodisation' of state activity, in order "to generate....insights into the trajectories of state rescaling in different global regions and national state spaces”. This approach entails a delineation of the different 'phases' of state rescaling under contemporary capitalism in order to uncover the processes behind such changes, as well as the consequences of them.

A concern over the crafting of certain structures and scales for intervention leads into a broader consideration of scale and the concepts of 'statecraft' and 'scalecraft'. With reference to statecraft, the work of Bulpitt (1983, 1986a; 1986b) is of relevance. 
Bulpitt (1986b, p.21) defined statecraft as "the art of winning elections and achieving a necessary semblance of governing competence in office”. In addition, Fraser (2010, p.335) has also defined statecraft as "the craft that states practice when they act politically”. This highlights the motives and behaviours of states and governments and how politics and power - as well as broader structural issues - are important in shaping behaviour (Buller and James, 2012).

Bulpitt's work particularly focused on the successive Conservative governments that were elected into office in the UK during the 1980s and the structural context (i.e. the political and economic system) within which politicians operated. In particular, he highlighted how gaining and retaining power in British politics was related to four specific statecraft functions or tasks to be carried out throughout a statecraft cycle that spans the period between elections: i) governing competence; ii) political argument hegemony; iii) party management and iv) developing a winning electoral strategy (1986b, pp.21-22).

In terms of governing competence, Bulpitt (1986, p.22) notes how this revolves around policy choice and implementation, and with the promulgation of ideas and policy choices that can be achieved within the constraints of the British polity. In so doing, this will project a reputation of 'governing competence', especially in terms of economic management, and at the same time help to facilitate a 'winning electoral strategy' through a policy package that is both effective and attractive. Tied to such tasks is the statecraft function of 'political argument hegemony', in terms of a “party’s arguments becoming generally accepted, or because its solutions to a 
particularly important problem seem more plausible than its opponents” (Bulpitt 1986b, 21).

However, Bulpitt's work has been criticized due to the ambiguity apparent with reference to operationalizing the various statecraft functions (Evans, 2006). In response, this paper empirically considers such statecraft functions in the context of the reorganisation and rescaling of local government in Wales in 1974 and 1996 respectively.

The latter point highlighting the significance of rescaling also draws attention to the notion and importance of scale itself. A rich array of empirical and theoretical work (Brenner, 2004; Jessop, 2002; Jones and MacLeod, 2004; Keil and Mahon, 2009; Swyngedouw, 2000) has shown how the recent reconstitution of the state under contemporary capitalism has involved a reworking of the state's "scalar architectures”. In Brenner’s terms (2009a, p.126), “no longer, then, are the scales of statehood conceived as stable platforms of institutional organisation”, but instead, "state scalar structures are now understood to be historically malleable: they may be ruptured and rewoven through the very political strategies they enable”.

Linked to the malleability of institutional organisation, scales exist because social processes are scaled and are therefore best understood as being "the provisionally stabilized outcomes of scaling and rescaling processes; the former can be grasped only through an analysis of the latter” (Brenner 2009b, p.71, original emphasis). However, 'first round' debates on state rescaling were abstract in nature and placed more focus on macro-level interpretations of state re-territorialisation (Lobao et al., 
2009) than on detailed studies of rescaling processes. Consequently, there have been calls for 'second round' research to develop stronger and more reflexive explanatory frameworks (Brenner 2009a, p.132).

The paper responds to this call. A focus on scalecraft highlights that a wider range of actors - including states, social and political groups and individuals - are all involved in scalar practices (Fraser, 2010, p.334), and may be attempting to produce, restructure and re-scale local government. In so doing, they seek to create competitive advantages or establish associations or connections to represent their interests.

Nevertheless, if scale is viewed as a social product then deploying a new scalar discourse for local government or crafting or establishing new scales of working requires certain aptitudes, skills and / or experiences, and can entail failure, experimentation and learning (ibid., p.332; also see Jessop, 2001). As a political act, crafting new scales of working may be "tricky, messy and awkward......things are rarely easily produced” (Fraser 2010, pp.333-334). Indeed, a ‘scalar fix' may rely on its embeddedness within dense webs of relations to other scales and spaces (Brenner 2001, p.606): unexpected, uneven and intersecting geographies can impinge on practices of scalecraft (Fraser 2010, p.340). This is a pertinent point in the context of successive reorganisations (and the rescaling) of local government in Wales, whereby both spatial and temporal dimensions, as well as the political and economic context have been influential in shaping overall outcomes.

By drawing together these insights, two key issues emerge that inform the overall focus of this paper. First, whilst it is clear that a number of studies have considered 
the processes of statecraft and / or scalecraft in isolation or as distinct and separate (see Fraser, 2010; Buller and James, 2012, as well as the work of Bulpitt), little work to date has considered the ways in which they may be intimately connected. In this respect, the various statecraft functions that have been identified can all be linked to the rescaling of governance, as states seek to practice what they do partly through a scaling and rescaling of their activities. It is often through scalecraft that states seek to practice statecraft, and particularly in cases where the rescaling of governance is explicitly used as part of a broader political strategy. Different national governments may seek to reform structures of local government to deliver their policies and demonstrate the competence of their ideas. But the outcomes of top-down, sitespecific scalar practices cannot be guaranteed and the operation of what could be termed 'statecraft through scalecraft' is not a certain process. Consequently, the paper investigates the dialectical and recursive relationship between each and how such interconnections vary in respect of the successive reorganisations of local government that have taken place.

The focus on the importance of - and interconnections between - statecraft and scalecraft also contribute to a second key concern of the paper. This involves the development of a tighter specifying of the process of state rescaling. The paper explores how statecraft and scalecraft combine in different ways and at different times to inform the rescaling of the state. In turn, this provides a number of new insights into the contradictions of the 'layering' process (see Brenner, 2009a) that are associated with the successive re-scaling and reorganisation of local government. 


\section{Rescaling the state and local government reorganisation in Wales}

The era of modern local government in the UK began with the Local Government Act of 1888. Across England and Wales this created a system of 61 (predominantly rural) county councils and 61 single tier (predominantly urban) county boroughs with responsibility for issues such as education and roads. Subsequent Acts of 1894 and 1899 established a second tier of 688 Urban District Councils as well as 692 Rural District Councils (Byrne, 1994). These were responsible for issues such as local planning and council housing. A third tier of 6880 parish councils responsible for issues such as village greens, allotments and recreation grounds were also set up (Kingdom, 1991).

Despite the new system quickly becoming obsolete due to major social, economic and demographic changes, including processes of suburbanisation and urban sprawl (Keith-Lucas and Richards, 1978), the structure of local government outside of London remained largely intact until 1974. A key reason for inertia was that consecutive national governments saw more political costs than benefits to reorganisation (Cochrane, 1993). Little progress was made on this issue until the late 1960s because central government opposed change in case it lost its position of 'divide and rule' with smaller local authorities (Kingdom, 1991). A further issue that also delayed reform - and which has been a recurring issue in successive reorganisations - related to the desire to improve both the strategic efficiency and democratic accountability of service provision: no agreed alternative to the existing system could be decided upon because improving strategic efficiency was related to the introduction of larger / single-tier units, although this has been called into question 
repeatedly (Dearlove, 1979; Browne, 2014). In contrast, to improve democratic accountability, this required the retention of smaller authorities in a two-tier local government structure. Such assertions have also been challenged (see Chisholm 1995, Chisholm and Leach, 2008).

\section{i) 1974 local government reorganisation in Wales}

The concerns highlighted above - and which implicitly draw attention to the respective importance of the processes of statecraft and scalecraft - are considered with reference to the structural reorganisation of local government in Wales that took place in 1974 and 1996 respectively. From a statecraft perspective, local government reorganisation provided the opportunity for the state to engage in various statecraft tasks concerned with illustrating governing competence and political argument hegemony in terms of its proposed solutions for local government. However, a consideration is required of the mechanisms and craft of scalar practices that informed the reorganisation process in the context of securing statecraft through scalecraft.

In Wales, a desire by the national Labour government to develop an effective solution to the problems of local government (and indeed elsewhere in the UK) formally commenced in the immediate post-War (1945-) period with the establishment of the Trustham Eve Commission (and which became known as the Local Government Boundary Commission). Given the recognition that local government was failing to reach service thresholds and internalise externalities, particularly in respect of urban development extending beyond the boundaries of urban authorities (Robson, 1968), this led to a second Local Government Commission being appointed by a 
Conservative government in the late 1950s. Reporting in 1961, it advocated a reduction in the number of counties in Wales from 13 to seven to improve administrative efficiency (Boyne et al, 1991). However, progress stalled over the next ten years, partially given related problems of securing statecraft through scalecraft, and in particular due to the degree of experimentation evident in respect of attempts to craft a new a system (and scale) of local government that worked for the state, as well as contestation and resistance to such proposals.

For example, successive national governments "baulked at the challenge of breaking up the prestigious and powerful Glamorgan County Council in south Wales” (ibid., p.8) as part of a rescaling of local government in Wales. Equally, whilst a Royal Commission chaired by Redcliffe-Maud was created in 1966 to review local government - and which arguably may have supported the crafting of new scalar arrangements - its remit only applied to England. Hence in Wales, a White Paper produced by the ruling Labour government (1967) was premature given the proposals emanating from the Royal Commission for England. In turn, a further White Paper in 1970, which intended legislating on Redcliffe-Maud's recommendations through establishing three unitary authorities for urban Wales and a two-tier structure for rural Wales was "received most violently by many, including the counties of Glamorgan and Monmouthshire” (Secretary of State for Wales, Mr. Peter Thomas, cited in Hansard proceedings of House of Commons, 17 November 1971).

Subsequently, the Conservative party won the general election of 1970 and new proposals for reorganisation were set out - based centrally around their election manifesto - in another White Paper entitled The Reform of Local Government in 
Wales: A Consultative Document (Welsh Office, 1971). Reflecting a new attempt at securing statecraft through scalecraft, it proposed that a two-tier structure for local government of seven county councils and 36 districts should be created across the whole of Wales to facilitate strategic efficiency and improve democratic accountability.

This approach illustrates how the provisional recommendations of the previous government were used to inform - as well as justify - the crafting of new scalar practices for local government in Wales:

The proposals for Wales embodied in the Local Government Bill were broadly in line with the previous Administration.....it was a common factor in all successive proposals of the previous Administration that the greater part of the geographical area of Wales should be dealt with in this way (Secretary of State for Wales, Mr. Peter Thomas, cited in Hansard proceedings of House of Commons, 17 November 1971).

Thus, the crafting of new discursive and material scalar practices for local government in Wales during this period was not highly innovative. Rather, they were experimental and provisional, as well as functional in respect of attempts to improve efficiency and accountability. At times, they were also heavily contested. Indeed, there were long-standing concerns over the need to organise certain strategic functions for local government over a wider area in line with the idea that "big was beautiful' (Dearlove, 1979), and other functions more locally, and to amend boundaries "that have prevented proper planning strategies and transportation 
strategies developing” (Secretary of State for England, Mr. Peter Walker, cited in Hansard proceedings of House of Commons, 19 May 1971). What is also revealing is that the rescaling of local government was inherently related to deliberations over the functions that it should deliver, as well as how such services / functions should be managed. Only the financial aspects of local government were left largely untouched (Alexander, 1982).

In particular, it is instructive to particularly focus on local government proposals for South East Wales in the early 1970s to highlight the issues and challenges associated with the crafting of new scalar practices as it is here that the most interesting insights can be found. In this respect, the Conservative White Paper highlighted that:

There is good evidence that socially, economically and geographically, South East Wales falls into three well defined areas around Swansea, Cardiff and Newport...and with each integrated with the areas for which they are the service and commercial centres (Welsh Office 1971, paras.36-38).

Consequently, three counties were proposed for East Glamorgan (focused around Cardiff), West Glamorgan (focused around Swansea) and Gwent (focused around Newport, located to the east of Cardiff) - as well as 17 districts. The White Paper stated that leaving the existing county of Glamorgan untouched would be disadvantageous as "the county would be pulled apart by the competing interests of two major cities (Cardiff and Swansea) 40 miles from each other” (para.42). A second alternative of creating three counties based around Swansea, Cardiff and Merthyr (located to the north of Cardiff) was also dismissed: 
.....there should be no separation of areas which ought to be administered together for the purposes of town and country planning and transportation nor the creation of at least one authority (focused around Merthyr) comparatively weak in terms of rateable resources and lack of suitable land in seeking solutions to its problems (para.43).

However, the provisional and experimental nature of scalar practices can be identified with reference to a subsequent U-turn by the Secretary of State on proposals for South East Wales as the Local Government Bill passed through Parliament. Moreover, such a change in the proposed scalar arrangements illustrates a number of other influences of relevance in respect of determining the eventual outcome of new scalar arrangements for local government. These include: i) the importance the statecraft task of a "winning electoral strategy" in shaping rescaling processes that are deemed to work for the state; ii) new problems of scalecraft emerging as a wider range of actors seek to become involved in the craft of scalar practices; and iii) the subsequent implications for securing statecraft through scalecraft - as such, this can never be guaranteed.

Indeed, rather than creating just East Glamorgan and West Glamorgan, the Bill now made provision for three authorities - West Glamorgan, Mid-Glamorgan and South Glamorgan, and with the new revised proposals (for South Glamorgan) entailing the merging of Cardiff and the Vale of Glamorgan (a majority Conservative-voting area). For many, this was seen as an attempt at party political gerrymandering, and as part of the Conservative party in Wales' statecraft ambitions of securing a winning electoral 
strategy through the development of alternative scalar arrangements for local government:

He has maneuvered on behalf of his Conservative friends in Cardiff in a shameful way......In February, he completely rejected the proposals he now brings forward...... He has (now) created a weak authority in which we have the Rhondda, Aberdare, Merthyr, and Pontypridd—all Labour, we know—and he is making them, with their 500,000 people, one of the poorest authorities in the whole of England and Wales (Mr. George Thomas, Labour MP, cited in Hansard proceedings of House of Commons, 17 November 1971)

But what this also illustrates are the difficulties in securing statecraft through scalecraft: processes, events and relations (see Fraser 2010, p.342), as well as local politics, all impinge:

I had hoped that the idea of proposing two counties in East Glamorgan would attract some measure of support. Not a bit of it. Swansea Borough Council was prepared to accept the proposed boundaries of West Glamorgan, although it disagreed with the principle of having districts within it. However, the Glamorgan County Council insisted that, whatever else happened, the existing administrative county area must be retained intact as the whole or the major part of a new county. The Cardiff City Council and the Merthyr Tydfil County Borough Council, on the other hand, told me that, in their view, the interests of the northern and the southern parts of the proposed East Glamorgan County were fundamentally opposed. Faced with this general opposition to my 
proposals for East Glamorgan, I had to think again. I concluded that I could not ask Parliament to approve a proposal for an East Glamorgan County because a county council for this area would be seriously weakened by the strongly opposed interests within it (Secretary of State for Wales, Mr. Peter Thomas, cited in Hansard proceedings of House of Commons, 17 November 1971).

In this context, two further points also arise in respect of what we learn from this reorganisation of local government for a tighter specifying of state rescaling. First, the example of South Glamorgan - and its creation following the consultation on the initial White Paper - draws attention to the notion of 'scalar politics' (Mackinnon, 2011), but how outcomes are not always be one-sided. This is less recognized in the existing literature. There should be a concern with the way in which scale is used - or 'strategically deployed' - to differentially scale new processes and institutions of local government in Wales in the context of (previous) inherited scalar structures (adapted from Mackinnon 2011, p.33).

Indeed, the new structure and scaling of local government (of both counties and districts) facilitated an eventual outcome (see Figure 1) that was unusual in that it was generally acceptable to both national government and some (but not all) local actors in this part of Wales. The arrangements allowed the national Conservative government to pursue a number of statecraft ambitions through the establishment of the Vale of Glamorgan district council in what was a Labour-dominated county stronghold. Nevertheless, at the same time, local resistance ensured that the Valleys, Swansea and Cardiff were all kept apart and were able to pursue their own ambitions, 
and within a county structure that remained Labour-dominated (except between 1977 and 1981 in South Glamorgan). During this phase - and despite the increasing crisis of the welfare state - political concerns were therefore more important than economic considerations for reform, both at a national and local level and as witnessed through the uncoupling of the main cities from their hinterlands.

Second, it is apparent that such scaling - or rescaling - is open to contestation and resistance, and as witnessed in respect of the creation of three new counties rather than two in the context of Glamorgan. Whilst this is not necessarily a new finding, what is interesting from utilising a statecraft / scalecraft framework to study the restructuring and rescaling of local government in this instance is that it illustrates the speed at which the reconfiguration of the structures and scales of government took place. This means that there is a more immediate temporality and "adhocness" to scalecraft than what has been generally reported in the existing literature.

\section{INSERT FIGURE 1 HERE}

\section{ii) 1996 local government reorganisation in Wales}

The context for the structural reorganisation of local government in Wales in 1996 was very different than 1974 . The social-democratic era collapsed in the latter half of the 1970s and produced a fiscal crisis in which the capitalist economy became unable to sustain the services it required. As the decade progressed the fiscal crisis of the state deepened, and as a result local government budgets and responsibilities were 
tightened, as well as there being an increasing emphasis on better standards of management (Elcock, 1994).

The election of Margaret Thatcher as Prime Minister in 1979 and successive Conservative governments led to a rolling back of the frontiers of the state and enacted a further variety of reforms aimed at restructuring local government, especially its financial dimension. Cuts in public expenditure "reflected the Government's rejection of Keynesian economic management and their commitment to monetarism. Local government was selected as a particular target” (Stoker 1988, p.14).

As a result, the shift to neo-liberal market-based approaches to the delivery of public services provided a differing context, as well as influence, on local government restructuring. Given the emphasis on 'contracting out', competitive tendering and utilizing the private sector and other (unelected) quasi autonomous non-governmental organisations (quangos) to deliver particular services, it is unsurprising that the concept of the ‘enabling authority’ featured heavily in proposals for local government reform. As such, local government was seen as part of the problem, rather than the solution to the statecraft ambitions of central government.

The Government's continuing quest for controls on local autonomy and the introduction of the (extremely unpopular) community charge (or 'poll tax') provided a further backdrop for ideas about how local government should be reorganised. With regards to the latter, it was considered that further reforms of local government would allow the introduction of a new council tax to replace the community charge. 
Nevertheless, only the structural dimension of local government was specifically focused upon in relation to proposals for restructuring and rescaling. This undermined the whole process of scalecraft during this period.

In late 1990, John Major replaced Margaret Thatcher as leader of the Conservative party and Michael Heseltine became the new Secretary of State for the Environment in England. In Wales, David Hunt replaced Peter Walker as Secretary of State for Wales. Mr. Hunt immediately ordered a review of the structure of Welsh local government. But reflecting the previous experiences of the 1960s in respect of the experimental and provisional nature of scalar practices, there was an absence of an independent Local Government Commission to consider structural reform in Wales (and Scotland), as opposed to England. What was different to the previous reforms, however, was the broader economic context and concerns with securing efficiencies, marketization and an emphasis on private sector intervention. This led to the Secretary of State for Wales publishing the consultation paper - The Structure of Local Government in Wales (Welsh Office, 1991) - setting out the Government's preference for all-purpose unitary authorities. This was on the basis that the increasing emphasis on local authorities as enablers of services had diminished the principles of self-sufficiency and economies of scale that had informed the crafting of scalar practices for local government in 1974 (Welsh Office 1991, paras. 2.1 and 2.2). In addition, learning from the previous round of rescaling was evident both in the consultation paper and subsequent policy discourse and discussion in that it was highlighted that the system created in Wales in 1974 had been unreflective of local loyalties and traditions and inefficient and less accountable due to friction in the 
provision of services between the counties and districts (ibid., 2.5; also see Hambleton and Mills, 1993).

After considering a wide range of options, David Hunt forwarded three possible patterns of thirteen, twenty or twenty-four unitary authorities, using the (37) existing districts in Wales as building blocks. The 20 authority model was viewed as being particularly attractive (Welsh Office 1991, para. 4.4.) although he didn’t explain why. Once again, this illustrates how the crafting of new scalar arrangements was still provisional and experimental. Indeed, by the following year, the preference was for 23 unitary authorities based upon local loyalties, the historical context and the desire to secure strategic efficiencies and democratic accountability.

What we also see during this period is the Government using the consultation process to secure its statecraft ambitions through instigating a head-to-head contest between the counties and districts - both of whom had radically different rescaling proposals and with the Welsh Office acting as referee in a classic instance of 'divide and rule' (Thomas 1994, p.52). In this respect, the White Paper on the future of local government in Wales published on 1 March 1993 reduced the proposed number of new unitary authorities to 21 (Welsh Office, 1993), again illustrating the provisional nature of scalar practices. As the subsequent Local Government Bill (Wales) passed through parliament, John Redwood replaced David Hunt as Secretary of State for Wales and the ability to draw on earlier experiences relating to the 1974 reforms was reinforced in respect of influencing rescaling processes: 
The problem is not simply one of there being two tiers of local government. It is compounded by the fact that the two tiers share responsibility for certain functions....I have the transcript of an interview which the present Secretary of State, Mr. Redwood, gave.....the Secretary of State said: "What I think went wrong in 1973 was that at that time they chose county areas that were very large.....and in many cases they didn't draw the loyalty of people in the way in which the historic counties have done...so the reform that I'm proposing now does restore the old counties, where that is possible, where they are a community and where they're a sensible size" (The Lord Advocate Lord Roger of Earlsferry, cited in Hansard proceedings of House of Lords debates, 14 December 1993).

But in contrast to 1974 when there was general consistency between successive national governments and the main political parties over restructuring and rescaling strategies - including adoption of previous ideas for change - this time the main political parties differed considerably in respect of their ideas for the development of new scalar arrangements for local government. In particular, the main party in opposition to the ruling Conservative government at the time - the Labour party advocated a new tier (or scale of government) in the shape of a Welsh Assembly or Parliament sitting above the proposed unitary authorities to facilitate a broader process of the devolution of power. Such arguments also highlighted the views of many (see Chisholm, 1995) that any attempt at restructuring and rescaling required a broader consideration of the role and function of different tiers of government, including local government: 
We recognise that any sensible reform of government in Wales has to include reform of all tiers of government......a Welsh Assembly or Parliament would provide precisely the right mechanism for the strategic planning and coordination of the services that are delivered by the unitary authorities but that would require such an overview (Ron Davies, Labour MP, cited in Hansard proceedings of House of Commons, 15 March 1994).

This led some commentators to suggest that scalar arrangements being proposed by the ruling Conservative government would be prone to failure given that that the crafting of new scalar practices to secure statecraft was being undermined through the Conservatives only considering a single dimension of local government, as well as a partial or selective use of existing evidence (Chisholm 1995, p.567). In essence, the three key reasons set out in the local government White Paper to justify a further round of restructuring and rescaling of local government could be challenged if a more detailed consideration was undertaken of the evidence base behind the assertions set out:

Let us go back to basics and to the White Paper...First: "the present system of local government in Wales is not widely understood"." "By whom is it not understood?", we may ask. What examination of which people was undertaken in order to establish that truth? And who marked the examination papers? Next, the White Paper states that the present system does not: "sufficiently reflect people's identification with their own communities and localities".” How did the Government assemble the evidence which forced them to conclude that identification with their community was so important to all 
Welsh people that they simply must have more of it, and that this was the way to give it to them? Thirdly, the Government find that: "it is now clear that the replacement of the old counties ... has not secured wholehearted public support".” Again, I ask, "How did they quantify the wholeheartedness of this support or the lack of it? (Lord Morris of Castle Morris, cited in Hansard proceedings of House of Lords debates, 14 December 1993).

Rather, it was claimed by opposition members of parliament (MPs) that the proposals could be interpreted more politically, and that new attempts at scalecraft were devoid of any substantial coherence and were simply being used to secure an alternative statecraft task of a winning electoral strategy by the Conservative party in Wales:

The true explanation of the Bill is that Welsh Office Ministers decided to produce a weaker local government structure, whose leaders would be less able to stand up to the Welsh Office; and at the same time to increase further the power and patronage of the Secretary of State (Lord Prys-Davies, cited in Hansard proceedings of House of Lords debates, 14 December 1993).

Thus many interpreted reorganisation as about “constituting fewer 'clearance points' in the implementation of policy emanating from the centre” (Boyne and Law 1993, p.554). But as legislation progressed, two other influences also became apparent with reference to influencing the new scalar arrangements. The first involved a combination of historical context coupled with a degree of path dependency, and with processes of scalecraft particularly seeking to reflect upon the previous administrative and ceremonial structures of local government in particular areas. Coupled to such 
influences was the importance of local political contestation and resistance, and which also led to a further re-shaping of scalar practices. Again, this was most apparent with reference to Merthyr:

Following the (contested) debates in Parliament and in Wales I have decided that there is a good case for a unitary Merthyr and a unitary Blaenau Gwent. Although I am reluctant to increase the number of authorities in the Bill, I understand the differences between Merthyr and its proposed partner in Blaenau Gwent. I understand Merthyr's long, proud history and its former status as a county borough. Its size, which is comparable to that of Cardiganshire and Anglesey, also works in its favour” (John Redwood, Secretary of State for Wales, cited in Hansard proceedings of House of Commons, 15 March 1994).

This increased the total number of new unitary authorities to 22, and which became operational on 1 April 1996 (Figure 2). However, the Secretary of State was quick to reiterate that his predecessor had not failed in respect of earlier proposals for the crafting of new scales and structures of local government in Wales; merely that he had placed further emphasis on the importance of historical context in order to tweak the nature of the new scalar arrangements being implemented:

Merthyr Tydfil was the only county borough whose former historic status was not recognised in the White Paper proposals......(but) my predecessor's judgment was right (John Redwood, Secretary of State for Wales, cited in Hansard proceedings of House of Commons, 15 March 1994). 


\section{INSERT FIGURE 2 HERE}

Interviews conducted with those working in local government in various parts of Wales at the time also highlighted how such discursive and material practices of scalecraft were being used, but with an interesting twist in respect of delivering statecraft. In essence, it was claimed that by coupling a rescaling of local government to the concept of the enabling authority, and limiting the finances of local government, this would lead to perceptions of governing incompetence locally and which in turn would help to facilitate national statecraft ambitions:

What is going to happen now is that they are going to say 'here is the reorganisation of local government; these are the ideas we had, they've cocked it up'. What they won't say is the amount of money which was available..... (Leader of Plaid Cymru group, Ceredigion County Council, Wales).

Thus in this second round of reorganisation in Wales, whilst broadly similar strategies of statecraft are evident, the practices of scalecraft to secure statecraft are different. In contrast to the 1974 reorganisation and the introduction of the two-tier system, the emphasis on crafting a new structure and system of local government based on unitary authorities (predominantly based on the old districts but with variations across Wales) was viewed by many as part of a broader statecraft strategy of central government to generate fewer 'clearance points' to impose its own agenda, as well as part of a broader strategy involving the increasing centralization of power. Consequently, the outcome was profoundly unsatisfactory to a number of actors beyond central 
government given the structural outcomes in many parts of Wales, the lack of discussion on the functions, management and finance of local government, the costs of supporting transition and the lack of deliberation on devolution proposals to create an overarching Welsh Assembly (Pemberton, 2000).

Coupled to this were the contradictions of the layering process associated with the successive re-scaling of local government in Wales. Addressing the problems of the two-tier system in respect of issues of duplication, lack of co-ordination and inefficiency proved to be difficult given the emphasis on developing a structural and scalar solution that sat between the existing counties and districts, and through the implementation of a 'set piece' unitary structure across the whole of Wales, regardless of context (such as population thresholds; rateable values etc).

In respect of scalar politics and the rescaling of local government structures, the example of Merthyr illustrated that statecraft through scalecraft was by no means guaranteed, and that the construction of scale can be contested or resisted by both local and national actors existing both within and beyond the state, and which can lead to subsequent reconfigurations as new political projects come into contact with inherited scalar structures (also see Mackinnon, 2011; Allen and Cochrane, 2010). As such, the reforms brought an increasing politicization of decision-making and a marked transition in local power structures. Therefore, in many areas of Wales the clock was turned back to the pre-1974 arrangements and the return of once powerful power blocs (Pemberton and Goodwin, 2010). Scalecraft - in respect of new scales of local government - entwined with historical and inherited spatial structures and scales of local government dialectically to strategically empower some actors, interests and 
strategies over others.

Consequently, from a temporal aspect, with this set of reforms we can identify a 'twospeed' approach to the (re-)crafting of scale. This is also less charted in the existing literature. On the one hand it is possible to witness the fairly immediate rescaling and re-crafting of scale as proposals for reform moved from consultation to becoming an Act in law - and in many instances driven by local political contestation and resistance. But on the other, such strategies of scalecraft and statecraft reflected a culmination of evidence, argument and discussion that had been accumulated for reorganizing local government over a much longer timeframe (for example, between the reforms of 1974 and 1996).

\section{Conclusion}

Overall, it is possible to discern a number of differences across the 1974 and 1996 reorganisations of local government in Wales in relation to processes of scalecraft to deliver statecraft. Whilst a degree of experimentation and contestation are emblematic of both sets of reforms, as well as the political statecraft ambitions of central government, there are notable differences in the crafting of scalar practices in the context of each round of reorganisation. These include i) the distinctive institutional, political and socio-economic contexts that influenced scalecraft, and in particular the importance and influence of the broader economic context on the role of local government (arguably more influential in 1996); ii) the dimensions of local government being addressed (far narrower in 1996 but crucial in the context of proposals to devolve more power to Wales in the form of a Welsh Assembly 
Government); iii) the extent of 'path dependency' evident between successive national governments in respect of developing similar ideas for restructuring and rescaling (this differed considerably between the 1974 and 1996 reforms); iv) the (partial) use of evidence based on previous reorganisation to inform scalar practices (much more evident in 1996); and v) the assertion of local governing incompetence to inform the national government's scalecraft and statecraft ambitions (again particularly evident in 1996).

What we also learn in respect of local government restructuring is that the craft of scalar practices is always provisional, experimental and contested. Statecraft through scalecraft cannot be guaranteed. There is also a need to look beyond the structural dimension of local government to understand practices of scalecraft: the functional, managerial and financial dimensions of local government may be of equal importance in shaping rescaling processes, although it is clear from the 1996 reorganisation of local government that such issues were not specifically focused upon. In turn, this impinged on the types of solutions proposed, and it was perhaps inevitable that those opposing the proposed reforms highlighted the need for a broader consideration of the functions associated with different tiers of government, including proposals to devolve further power to Wales.

In this respect, the election of the Labour party into office in 1997 placed devolution firmly on the agenda as part of a wider attempt to accommodate national and cultural diversities; to address calls for the wider democratization of governance; to secure opportunities for public sector modernization; and to adapt to changing functional economic and social restructuring (Keating 2006). In Wales, this led to the creation of 
the Welsh Assembly Government in May 1999, and which has taken responsibility for local government in Wales. Subsequently, the Welsh Assembly has embarked on a programme for the modernization of public sector government (Pill, 2011) and which has included the restructuring and rescaling of other organisations in Wales, such as the health and police authorities.

This is important as contemporary proposals for the further structural reorganisation of local government in Wales are using the boundaries of the Local Health Boards (LHBs) and the police force to shape the rescaling of local government. In essence, the boundaries of the new local authorities must align with / be contained within such structures (Welsh Assembly Government 2014, para.85). What this appears to confirm is how "emergent rescaling strategies collide with, and only partially rework inherited landscapes of state scalar organization” (Brenner 2009a, p.134).

However, investigation of the scaling of the LHBs reveals that a chronology of their development leads back to their predecessors being largely based around the eight local government counties created through the 1974 reorganisation. So what we see in reality are two previous attempts at scalecraft (in terms of local government reorganisation) informing the crafting of scale for LHBs, and which are now subsequently informing contemporary rescaling and restructuring proposals for local government in Wales. Thus Brenner's arguments relating to rescaling strategies and inherited landscapes of state scalar organization can be developed further. For example, the analysis of contemporary proposals for local government reform in Wales highlight how emergent rescaling strategies (e.g. in respect of local government) may collide with rescaling strategies of other aspects of the state (e.g. 
health). In turn, these may only be minimally re-worked in certain places at certain times (witness the need for mergers within existing boundaries) and indeed can become defunct before they have any real opportunity to re-work existing structures. Such structures themselves may also reflect both past (i.e. previous local government arrangements) and contemporary landscapes (i.e. LHBs) of state scalar organization.

This finding can be coupled with other new insights highlighted in this paper to generate a tighter specifying of rescaling, namely: i) the outcomes associated with scalar politics not always being one-sided and thus meeting the expectation of both national / local and state / non-state actors; ii) the temporality of scalecraft and how this may lead to reconfigurations of scale in both the short and longer-term; and iii) the 'layering' process being complex, involving multiple structures, strategies and scales of the state, and the importance of both past and contemporary landscapes of state scalar organization in shaping both existing structures of government and emergent rescaling strategies.

Further exploration of such issues in differing contexts, over differing time periods and involving different national and local political agents would therefore be useful in terms of confirming or challenging such findings, and their relative importance in either enabling or constraining processes of reorganisation and rescaling.

\section{Bibliography}

Allen J, Cochrane, A, 2010, “Assemblages of state power: topological shifts in the organization of government and politics” Antipode 42 1071-1089. 
Alexander A, 1982, Local Government in Britain since Reorganisation (Allen and Unwin, London).

Boyne G A, Law J, 1993, "Bidding for unitary status: an evaluation of the contest in Wales” Local Government Studies 19(4) 537-557.

Boyne G A, Griffiths P, Lawton A, Law J, 1991, Local Government in Wales: It's role and functions Joseph Rowntree Foundation, York.

Brenner N, 2009a, “Open questions of state rescaling” Cambridge Journal of Regions, Economy and Society 2(1) 123-39.

Brenner N, 2009b, "Restructuring, rescaling and the urban question" Critical Planning Summer 2009 60-79.

Brenner N, 2004, New State Spaces: Urban Governance and the Rescaling of Statehood (Oxford University Press, Oxford).

Brenner N, 2001, "The limits to scale? Methodological reflections on scalar structuration" Progress in Human Geography 25 591-614.

Browne A, 2014, "Will cutting the number of councils in Wales save money?", http://www.bbc.co.uk/news/uk-wales-politics-24582160; accessed 31 July 2014. 
Buller J, James, T S, 2012, "Statecraft and the Assessment of National Political Leaders: The Case of New Labour and Tony Blair” British Journal of Politics and International Relations 14(4) 534-55.

Bulpitt J 1986a, "Continuity, autonomy and peripheralisation: The anatomy of the centre's race statecraft in England” in Race, Government and Politics in Britain Eds Z Layton-Henry and P Rich (Basingstoke, Macmillan) 17-44.

Bulpitt J 1986b, “The discipline of the new democracy: Mrs Thatcher’s domestic statecraft”, Political Studies 34(1) 19-39.

Bulpitt J 1983, Territory and Power in the United Kingdom (Manchester: Manchester University Press).

Byrne T, 1994, Local Government in Britain 6th edition (Penguin, London).

Chisholm M, 1995, "Some Lessons from the Review of Local Government in England” Regional Studies 29(6) 563-569.

Chisholm M, Leach S, 2008, Botched business 2006-2008: the damaging process of reorganising local government (Douglas Maclean, Coleford).

Cochrane A, 1993, Whatever Happened to Local Government? (Open University Press, Buckingham). 
Commission on Public Service, Governance and Delivery, 2014, Full Report; http://wales.gov.uk/topics/improvingservices/public-service-governance-anddelivery/report/?lang=en; accessed 25 July 2014.

Cox K, 2009, "Rescaling the state in question" Cambridge Journal of Regions, Economy and Society 2(1) 107-21.

Dearlove J, 1979, The Reorganisation of British Local Government: Old Orthodoxies and a Political Perspective (Cambridge University Press, Cambridge).

Elcock H, 1994, Local Government in Britain (MacMillan, London).

Evans M, 2006, "Elitism” in The State: Theories and Issues Eds C Hay, M Lister and D Marsh (Basingstoke, Macmillan) 39-58.

Fraser A, 2010, “The craft of scalar practices” Environment and Planning A 42(2) 332-46.

Hambleton R, Mills L, 1993, “Local Government Reform in Wales” Local Government Policy Making 19(4) 44-55.

Hansard, 1994, Commons Debates: Daily Hansard - Written Ministerial Statements 15 March 1994;

http://www.publications.parliament.uk/pa/cm199394/cmhansrd/1994-03-15/Debate1.html; accessed 25 July 2014. 
Hansard, 1993, Local Government (Wales) Bill - House of Lords Debates, 14

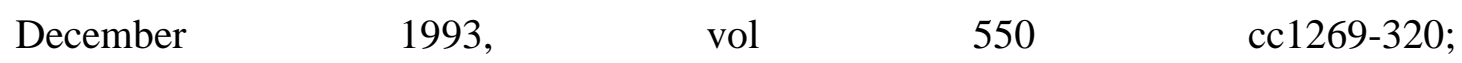
http://hansard.millbanksystems.com/lords/1993/dec/14/local-government-wales-billhl\#S5LV0550P0_19931214_HOL_112; accessed 8 January 2015.

Hansard, 1971, Commons Debates: Daily Hansard - Written Ministerial Statements 17 November 1971; http://hansard.millbanksystems.com/commons/1971/nov/17/local-government-bill; accessed 25 July 2014.

Hansard, 1971, Commons Debates: Daily Hansard - Written Ministerial Statements 19 May 1971; http://hansard.millbanksystems.com/commons/1971/may/19/localgovernment-in-england-white-paper; accessed 08 January 2014.

Jessop B, 2002, The Future of the Capitalist State (Polity Press, Cambridge).

Jessop B, 2001, “Institutional (re)turns”, Environment and Planning A, 33 1213-35.

Jones M, MacLeod G, 2004, "Regional spaces, spaces of regionalism: territory, insurgent politics and the English question” Transactions of the Institute of British Geographers, 29(4) 433-52.

Keating M, 2006, "Nationality, devolution and policy development in the United Kingdom” in Territory, identity and spatial planning: Spatial governance in a 
fragmented nation Eds M Tewdwr- Jones and P Allmendinger P (Routledge, London) 22-34.

Keil, R, Mahon R, 2009, Leviathan Undone? Towards a Political Economy of Scale. (University of British Columbia Press, Vancouver).

Keith-Lucas B, Richards P G, 1978, A History of Local Government in the Twentieth Century (Allen and Unwin, London).

Kingdom J, 1991, Local Government and Politics in Britain (Phillip Allan, Hemel Hempstead).

Labour Government, 1970, The Reform of Local Government in Wales (HMSO, London).

Lobao, L, Martin R, Rodriguez-Pose A, 2009, "Rescaling the state: new modes of institutional-territorial organization” Cambridge Journal of Regions, Economy and Society, 2(1) 3-12.

MacKinnon D, 2011, “Reconstructing scale: Towards a new scalar politics” Progress in Human Geography 35(1) 21-36.

Pemberton S, 2000, “The 1996 Reorganization of Local Government in Wales: Issues, Process and Uneven Outcomes” Contemporary Wales 12(5) 77-106. 
Pemberton S, Goodwin M, 2010 “State power, local government reorganisation and accumulation and hegemony in the countryside” Journal of Rural Studies 26(3) 272283.

Pill M, 2011, Neighbourhood management: development of an assessment framework (Cardiff University Press, Cardiff).

Pratchett L, Wilson D, Eds 1996, “Local Government Under Siege” in Democracy and Local Government Eds L Pratchett and D Wilson (MacMillan, London) 1-19.

Redcliffe-Maud, 1969, Report of the Royal Commission on Local Government (HMSO, London).

Robson W A, 1968, Local Government in Crisis (Allen and Unwin, London).

Stoker G, 1988, The Politics of Local Government (MacMillan, London).

Swyngedouw E, 2000, “Authoritarian governance, power and the politics of rescaling” Environment and Planning D: Society and Space 18(1) 63-76.

Thomas A, 1994, “The myth of consensus: The Local Government Review in Wales”, in Contemporary Wales; An Annual review of Economic and Social Research Eds G Day and T Dennis (University of Wales Press, Cardiff) 47-60. 
Welsh Assembly Government, 2014, White Paper - Reforming Local Government (Welsh Assembly Government, Cardiff).

Welsh Office, 1993, Local Government in Wales: A Charter for the Future - White Paper (HMSO, Cardiff).

Welsh Office, 1991, The Structure of Local Government in Wales: A Consultation Paper (HMSO, Cardiff).

Welsh Office, 1971, The Reform of Local Government in Wales: Consultative Document (HMSO, Cardiff).

Welsh Office, 1967, Local Government in Wales (HMSO, Cardiff). 